Man and Nature

L'homme et la nature

\title{
The Art of Medicine in Pre-Loyalist New Brunswick
}

John Mackay

Volume 4, 1985

URI : https://id.erudit.org/iderudit/1011842ar

DOI : https://doi.org/10.7202/1011842ar

Aller au sommaire du numéro

Éditeur(s)

Canadian Society for Eighteenth-Century Studies / Société canadienne d'étude du dix-huitième siècle

ISSN

0824-3298 (imprimé)

1927-8810 (numérique)

Découvrir la revue

Citer cet article

Mackay, J. (1985). The Art of Medicine in Pre-Loyalist New Brunswick. Man and Nature / L'homme et la nature, 4, 139-154. https://doi.org/10.7202/1011842ar

Copyright (c) Canadian Society for Eighteenth-Century Studies / Sociéte canadienne d'étude du dix-huitième siècle, 1985
Ce document est protégé par la loi sur le droit d'auteur. L'utilisation des services d’Érudit (y compris la reproduction) est assujettie à sa politique d'utilisation que vous pouvez consulter en ligne.

https://apropos.erudit.org/fr/usagers/politique-dutilisation/ 


\section{The Art of Medicine in Pre-Loyalist New Brunswick}

There is of course an inherent contradiction in the expression 'PreLoyalist' New Brunswick, because in a political and geographic sense New Brunswick only came into existence in 1784, the year following the arrival of the Loyalists, and in fact its exact boundaries were not defined until many years later. In 1713, by the Treaty of Utrecht, France ceded 'Acadia with its ancient limits' to Britain. Unfortunately, there was no agreement on what constituted the 'ancient limits'. ${ }^{1}$ The French claimed they had surrendered only the mainland of modern Nova Scotia, bounded by the Isthmus of Chignecto, whereas the British claimed that 'Acadia' included the entire mainland south of the St. Lawrence River. So the dispute over ownership, which was already a century old, continued for another fifty years until the end of the Seven Years' War in 1763, when the French claim to title was finally abandoned. Even then, the British took little interest in the area until the end of the American Revolution in 1783, when the arrival of thousands of Loyalists within a few months changed its character forever.

During most of the 18th century what is now New Brunswick consisted of a wilderness of forests and lakes, lying between New France (Quebec), New England (Maine) and New Scotland (Nova Scotia), of which the British at least considered it to be a part. Its boundaries were poorly defined, its ownership was constantly disputed, and its history from a European perspective was largely obscured by the more colorful activities of Quebec and Louisbourg, Halifax and Boston. There were no 
important battles, no large cities or fortifications, and not much direct contact with European civilization, an essential fact in the appreciation of the character of the indigenous health care system.

Who lived in New Brunswick before the Loyalists? Apart from a handful of New England traders located for example at Maugerville near present day Fredericton, and at the mouth of the Saint John River, the entire population consisted of two groups: Indians and Acadians.

\section{INDIAN MEDICINE}

It is hard to say just how many Indians lived in New Brunswick in the eighteenth century. There was no accurate census, and estimates vary, no doubt in part because of the effects of migration, famine and epidemic, as well as the uncertainty of whether figures refer to all members of a certain tribe, or only those in a particular geographic area. In comparing various sources, it seems a reasonable guess that the total Micmac population in mid-eighteenth century was on the order of three thousand, ${ }^{2}$ of whom less than half lived in what is now New Brunswick. Allowing for a smaller number of Malecites, we may conclude that the total Indian population of New Brunswick in the eighteenth century was not more than two or three thousand. It is believed to have been much higher before European contact, ${ }^{3}$ falling to its lowest point around 1700. This was followed by a gradual increase in the eighteenth century, relative stability in the nineteenth, and a rapid increase since 1900.

The Indians of New Brunswick were a nomadic people who lived by hunting, fishing and gathering. The search for food dominated their lives. ${ }^{4}$ They did not practise agriculture prior to contact with Europeans, and firmly resisted various European efforts to turn them into farmers. ${ }^{5}$ The Indians placed little value on accumulating a surplus of goods or food either individually or collectively. Their tools were made of wood, stone, bone or shell, and their food consisted of fish (such as smelt, cod, lobster, crabs, eel, clams and oysters), game (such as seals, walrus, beaver, moose, bear and wildfowl), roots, berries and nuts. They had some knowledge of preservation by smoking and drying, but in general they tended not to stockpile. Even within this limited and precarious source of food they were inhibited by numerous taboos. For example they tended not to eat carnivores or pregnant females; it was believed that to eat a chickadee would make one a liar and it was forbidden to kill a porcupine near camp.

There was a marked division of labor. At the risk of oversimplifica- 
tion, one might say that men hunted, fought and made canoes, snowshoes and weapons, while the women did everything else. ${ }^{6}$

The average amount of territory to support two hunters and their families has been estimated at four hundred square miles. ${ }^{7}$ Although the Indians of New Brunswick clung to their aboriginal lifestyle for two centuries following European contact, in the end as always the Europeans wreaked devastation on the Indians. Following the end of the French Regime there came an increasingly rapid decline in both culture and independence, although the population, which had decreased markedly since pre-contact, began to stabilize.

From the mid-sixteenth century, missionary priests had undermined the authority of the tribal elders and consequently of tribal traditions, while European technology made the Indians increasingly dependent on manufactured trade goods, less and less able to survive by means of their original primitive artefacts. ${ }^{8}$ Alcohol and epidemics completed their downfall. Severe famines in 1729, 1733, 1737 were interspersed with a smallpox epidemic originating around Louisbourg in 1732-1733.

The Indians' pre-contact life apparently was healthy. Studies of precontact skeletal remains suggest an average life expectancy of 37 which was only attained by Europeans in the nineteenth century, ${ }^{9}$ and there are many anecdotal reports of individuals reaching advanced ages. Early descriptions of the New Brunswick Indians emphasized their vigor, and strength, and the absence of disease and deformity.

One of their chief medical problems was digestive disorders in both infants and the aged..$^{10}$ The practise of making the baby's first mouthful a swallow of fish oil or melted fat ${ }^{11}$ may have contributed to infant mortality, but the danger for adults was the gluttonous manner of eating. Game was consumed all at one time, frequently followed by a fast of many days. From 15-20 pounds of meat per person might be consumed at a sitting. ${ }^{12}$ Food was typically undercooked, so parasitism was probably common.

The restricted degrees of consanguinity were $f e w,{ }^{13}$ so one may speculate that hereditary disease may have been common.

Childbirth was a simple process that took place in the open rather than inside a wigwam. The mother was delivered on her hands and knees; a decoction of ash leaves was prepared to ease the pain and binders were used on the abdomen of both mother and baby to control postpartum bleeding. As soon as the baby was born it was washed in cold water, a practise which no doubt promoted natural selection, especially in winter. On the other hand, it should be noted that the Indians' treatment of children was in general much more humane than that prevailing in eighteenth-century Europe. 
Medicine among the Indians had two levels, magical and practical. ${ }^{14}$ They believed that evil influences caused all disease not due to an obvious external cause. It might be due to the malevolent spirit of an offended animal or instigated by a human enemy with supernatural powers. It is important to realize that the supernatural played a preeminent part in every aspect of Indian life. Everything, animate or inanimate, had a spirit power which governed its existence and its relationship to humans.

Most of the health problems suffered by the Indians were associated with exposure, accident and famine. Early explorers remarked on the absence of palsy, dropsy, gout, rheumatism, stone, bilary colic and asthma among the natives, and only after the arrival of Europeans did they suffer from typical European diseases such as measles, scarlet fever, diphtheria, smallpox, typhus, typhoid, malaria, yellow fever, tuberculosis, venereal disease and alcoholism.

The Indians believed that dancing preserved health, bleeding preserved youth, and they took sauna baths in specially constructed pits or wigwams. They massaged their bodies all over with seal oil, which helped them withstand heat, cold and mosquitoes.

Scurvy was prevalent, and got worse when the Indians became dependent on white settlement in times of famine. It was effectively treated by a tea made of spruce or hemlock twigs and bark.

\section{MAGICAL (SUPERNATURAL) MEDICINE}

Magical healing was the prerogative of an official priest-physician (shaman or buoin), whose secrets were handed down from father to son. He was of great importance, second only to the chief, and was feared and respected because he could exorcise, prophesy, converse with spirits and confound his enemies as well as heal the sick. Healing was conducted by a combination of prayer, song, dance and fetishes (pebbles, thorns, carvings, drawings, etc). At the end of his ceremony he would suck, blow or lick the affected part to extract the active principle of the disease, producing by sleight of hand a thorn or pebble which was thrown away.

Another variation of this ceremony was to bury a stick attached to a cord. This was followed by a frenzied dance, the stick was pulled up by the cord and would found to be attached to some object representing the disease. Whatever the limitations of his medical knowledge, it is clear that the shaman had to be a skilled practical psychologist. He would obviously have required a high degree of persuasiveness and charisma, enormous self-confidence and a degree of manual dexterity in order to 
mystify and convince his audience. (It is stated, moreover, that the shaman required his fee in advance!)

These shamans were powerful, with great psychological influence. They could control even a strong chief and determine war or peace. Occasionally it was said that they might be murdered if their magic failed, so they had to be effective prognosticators. If they prognosticated death, the victim would stop eating. If he failed to die in a reasonable time, cold water was poured on him and occasionally his sufferings were terminated with a blow on the head. It seems probable that on occasion the shaman's prognosis became a self-fulfilling prophecy!

\section{PRACTICAL MEDICINE AND SURGERY}

The herbalist was a lower rank of medicine man. He had a large armamentary of herbs and remedies, at least as complex and probably as effective as the European medicines available at the time. A few examples will be sufficient for our purpose. Nervousness was treated by a potion prepared from the fine roots of Lady's Slipper. Scurvy, coughs and colds were treated with teas from hemlock bark or the needles and twigs of spruce and pine. Sore throat was treated with a similar preparation of the Staghorn sumac. The inner bark of the elder could serve two purposes: obtained by scraping downward it functioned as a purgative and by scraping upward as an emetic! Earache was treated in a variety of ways which included tobacco smoke, skunk grass or tea of boiled sumach, variously inserted in the ear canal. Porcupine urine dropped into the ear and retained by a plug was held to be of value in the treatment of defective hearing. Urinary troubles were treated with a tea prepared from the white pine, and bleeding hemorrhoids were treated with a white oak bark steeped and drunk. Swollen lymph nodes were treated with a juice of steeped high bush cranberries. Warts could be removed by rubbing them with raw meat which was then discarded.

The Indians knew how to treat superficial wounds, fractures, and dislocations, a fact remarked upon by the early French. They were familiar with forms of bandaging, bone setting, cauterizing, counterirritation, and cupping. They knew techniques of poulticing, scarifying and venesection. They applied cold fomentations to bruises and treated various wounds and sores with fir balsam which when chewed or heated could be used as a kind of salve. They closed incised wounds by sutures made of inner bark or the tendons of deer. Beaver kidney was used for a poultice following an incised wound. Beeswax or juniper was applied to 
cuts. Skin ulcers were treated by the underbark and juice of juniper berries. Padded splints were used for fractures.

The Indians used flint knives to amputate at joints and red hot irons to cauterize bleeding vessels. Hemorrhage was treated by dried powders of vegetable origin. Some of the early writers observed that they had no treatment for toothache since all appeared to have perfect teeth.

Near drowning was treated by hanging the victim over a branch, head down. A piece of animal gut, ordinarily used for carrying fats and oils, was filled with tobacco smoke which was blown into the patient's lungs (and even less likely orifices) to make him cough up water.

\section{THE ACADIANS}

Before the arrival of the United Empire Loyalists in 1783, the non-Indian population of what is now New Brunswick consisted almost exclusively of a small number of French settlers whose descendants became identified as 'Acadians'. Early attempts at colonization of Acadia by the French had occurred in 1604, 1605 and 1610, but there were few Acadians by any definition before 1632, when the Company of New France transported some three hundred settlers to La Have (in modern Lunenburg County, Nova Scotia). ${ }^{15}$ Many of these later moved to Port Royal, and in the following years secondary colonies appeared in the areas of Minas Basin and Chignecto Bay. These settlements developed steadily in spite of intermittent French-English hostilities.

Most of the settlers were employed in farming, fishing and trapping, but their numbers included various tradesmen such as carpenters, blacksmiths, gunsmiths, masons, coopers, bakers and so on.

By 1710 when Acadia finally fell to the English and French immigration ceased, the total Acadian population had risen to 1500-2000, mostly second to fourth generation. ${ }^{16}$ They were a homogeneous, familyoriented and self-reliant group with simple needs. They appear to have been relatively healthy ${ }^{17}$ and industrious; indifferent to luxury and independent of the mother country, they were skillful in a variety of pioneer trades which allowed them to obtain food, shelter and clothing from their own exertions and through trade with the New England colonies and Louisbourg.

By 1755-1758, the years of the dispersions, their total numbers probably did not exceed 8,000 to 10,000 , of whom perhaps two thousand lived in what is now New Brunswick, chiefly around Chignecto. Perceived as a threat to the feeble British sovereignty of the area, about threequarters of the total were driven from their homes and transported to 
various locations in other British colonies. With British rule assured by the Treaty of Paris in 1763, the displaced Acadians were permitted to return to the region, though not usually to their point of origin. By 1800, their population had again reached 8,000. It was only after the return that the main concentration of Acadians was to be found in New Brunswick, chiefly along the north eastern coast, rather than Nova Scotia and Prince Edward Island.

\section{ACADIAN MEDICINE}

The Acadian people had little contact with academic European medicine, apart from the medical knowledge of a few priests and even fewer 'surgeons' of doubtful qualification. ${ }^{18}$ European medicine was restricted to the military and religious practitioners at Port-Royal and later at Louisbourg in Ile Royale (Cape Breton). New Brunswick boasted no such outposts of civilization.

The expression 'être bâdré de ses vivres' - meaning indigestion represents the nature of traditional Acadian medicine. ${ }^{19}$ The Acadians described numerous ailments such as indigestion, colds, and rheumatism which were treated with a variety of folk remedies. They also had treatments for wounds, burns and infections.

But the traditional medicine was not a complete or well-defined system. There was no uniformity in the preparation of medical treatments, and no one was considered the supreme authority. They possessed simply a collection of oral traditions passed from one generation to another. The efficacy of these remedies was based on practical experience, and their composition was not established in any fixed way. Rather they were modified from one time and place to another, improvising where necessary, so that whatever seemed effective became accepted practise. Overall, simplicity dominated, both in the preparation of remedies and in the transmission of knowledge.

Traditional Acadian medicine was certainly not specific, but neither was it entirely superstitious or magic. Often the mother of the family would prepare an herbal remedy in the same way as she had seen her mother and grandmother do it before. Knowledge of the traditional medicine could in fact be transmitted to anyone, but there were certainly some people who took a particular interest and were recognized in their village as 'healers'. Among the latter, some used traditional remedies while others possessed 'gifts' or secrets which allowed them to cure certain maladies and care for certain injuries. 


\section{Categories of Healers in Acadia}

It is worth noting that traditional medicine survived in Acadia until well into the present century because people still treated themselves through necessity rather than choice. Many had no money or means of transport; doctors were few, epidemics were frequent, vaccines little known. So the Acadians, until our parents' generation, treated illness as best they could, with what materials were available: the plants that grew around the house, sea water, butter and salt. Certain persons ('Les Fabriquants de Remèdes') made folk medicines and sold them from door to door.

\section{The Influence of the Indians}

There was a long and close alliance between the French and Indians in Acadia - in fact many British officials following the conquest complained that they could not tell one from the other - and there is no doubt that an important part of the traditional Acadian medicine was derived from the Indians, such as the many uses of balsam and the remedy of the 'seven woods'. We are told that sometimes Acadians would travel for miles to consult the nearest group of Indians about a remedy for their disease. But the Indians did not readily reveal their knowledge; more often they would treat on the spot rather than give a prescription! By keeping their secrets and thereby the privilege of using them at their option, they maintained a certain distance from the white man, mixed with fear and respect, which helped gain their own ends. Acadian folklore abounds with stories of Indians having the power of sorcerers.

\section{The Transmission of Knowledge}

Whereas the Indians transmitted their medical knowledge orally on an individual basis, and not to just anyone, Acadian medicine was transmitted more generally from one generation to the next.

One can distinguish three categories of popular medicine. First was natural medicine, the most important, consisting of all the remedies made from plants (roots, herbs, flowers, trees, grains) in the form of herbal teas, plasters, poultices, etc. as well as those containing minerals (e.g. salt, sulfur) or animal products (eg. goose grease, cow dung, etc.) Next was a kind of magic medicine, often associated with natural medicine in the hope of obtaining better results. This itself was composed of three elements. 
A. There was the person who conducted the treatment or exercised the secret, which might be either a gift received at birth or transmitted later by a person of the opposite sex. Such people were often known for their ability to stop hemorrhage, cure earaches or toothaches or remove warts.

B. Then there was the propitious time chosen by the healer to exercise his art, often according to the phase of the moon or the movement of the tides. For example, childbirth was said to be easier during a quarter moon. Rheumatism was helped by putting the feet in salt water on the falling tide. There was also the question of time of day: herbal teas were more effective when taken early in the morning.

C. And finally there was the material used in making the magic gesture or reciting the magic formula: wood, stone, bread, ashes, hot cloths, etc. For example, to remove a wart one rubbed it with potato skins which then had to be buried by someone else. A febrile infant was wrapped in hot cloths to make it sweat.

Finally there was religious medicine, which consisted of expressions of faith such as recitation of novenas, prayers, or making the sign of the cross; or the use of sacred objects such as medals or holy water. For example, one might wear a cord of St. Joseph with nine knots around the waist for general protection, or place the diary of Sainte Anne on the patient to sooth internal pain, such as from a cancer.

\section{METHODS OF CURING}

Among the early Acadians, anyone might be a healer, but there was generally much more confidence in old people, no doubt because of their great experience of life. Farm animals were usually treated by men; women cared for everybody else. Obtaining a cure demanded a great deal of faith, which is no doubt why one hears so often of priests acting as healers. ${ }^{20}$ The priest was usually the best educated person in the village, serving as universal administrator and spokesman. Since he was responsible for saving souls, naturally people had confidence in him and many were reputed to be able to effect cures, sometimes on condition that the patient alter an unacceptable pattern of behaviour.

But these priests were only a small proportion of the healers. Each village had, in addition to all the mothers and grandmothers who cared 
for their families, a whole range of healers, who often specialized in a particular problem such as hemorrhage, toothache, warts, etc. Confidence was essential. Sometimes the victim needed only to think of the healer for his problem to be alleviated without the healer's actual presence. Some healers pronounced secret words, with or without turning or manipulating a fetish such as a stone or a wooden ladle. Sometimes healers themselves suffered or became weak as the patient's disease diminished.

The power of stopping hemorrhage was always transmitted to a person of the opposite sex; the more who were told the secret, the more the informant's power was reduced. The blacksmith was sometimes called upon to extract teeth, but a less painful solution was to see someone with the power to make the toothache stop, by such methods as putting a horseshoe nail in the tooth, then taking it to the forge. (Others used the point of a quill or spine.) There were many who could treat fractures by reduction and splinting. The splints were re-adjusted as the swelling diminished.

Apart from healers, each village had one or more mid-wives ('les sagesfemmes') usually old women with much experience. These practitioners continued to function until quite recent times, since it was often impossible, especially in winter, to have a doctor attend a childbirth. Their function included taking care of the house and family before and after the birth, not unlike the modern homemaker service. Their chief medical skills appeared to be breaking the amniotic membrane, cutting the cord and wrapping up the baby.

\section{TRADITIONAL ACADIAN REMEDIES}

There is neither space nor purpose in enumerating all of the herbal remedies which usually consisted of only a list of ingredients with little detail on quantities or methods of use. In any case many of those recorded were undoubtedly introduced later than the eighteenth century. It would require a botanist to describe all of the innumerable plants used at one time or another in traditional medicine.

A few of the more interesting ideas are given as examples. Sea-sickness was prevented either by wearing a bag of salt around the neck or by standing in a box of earth taken on board the boat. A child slow in learning to walk was thought to have weak kidneys which were treated by rubbing the area over the kidney with salt water in which potatoes had been boiled. Delayed menstruation could be brought on by dry mustard on the socks, and freckles could be removed by rubbing with buttermilk. To 
preserve good mental health it was believed that one should eat an entire fish including the head. Crooked legs could be straightened by burying them in the sand and anemia could be alleviated by drinking water in which a red hot iron had been quenched. Umbilical hernia in the newborn was prevented by fastening a small coin over the infant's umbilicus. To calm a fighting drunk it was recommended that one put salt in his socks so that the salt could draw the force of the alcohol.

\section{MEDICINE AT ILE ROYALE (Fort Louisbourg)}

It was noted earlier that the Acadians of New Brunswick had little contact with European medicine. By way of contrast it may be worthwhile to describe something of the practise of medicine at Fort Louisbourg, the nearest centre where professional treatment would be available. ${ }^{21}$

At the time of the Renaissance, surgery was highly regarded as a healing art, as it had been in ancient times. Both surgery and medicine were practised by the same men and were considered equally worthy of scholarly study. By the sixteenth century surgery was considered definitely inferior to medicine. Surgeons and barbers were classed together as artisans or manual labourers. Either the physician had lost interest in surgery because it was distasteful and less profitable than medicine or the scholars of the time, being clerics, were forbidden to shed blood and therefore hired laymen to perform surgical operations.

During the course of the eighteenth century the surgeons had begun to acquire a degree of independence and respectability, separated from the barbers as a learned profession, although still considered inferior to physicians. In point of fact, at this time surgery was probably the more effective of the two healing arts, and it was recognized that French surgeons were the best in Europe. Surgeons learned anatomy by dissection and treatment by apprenticeship, whereas physicians mainly studied theory with limited scientific basis. The real difference between the two lay in the types of disease treated. They applied more or less the same knowledge of healing, but applied it to different illnesses, or the same illnesses in different parts of the body. Thus surgery dealt with external illness or that which could be treated by operation or external remedies, for example wounds, ulcers, tumors, fractures and dislocations, skin conditions, sprains, hernias and toothaches.

Medical services in Ile Royale did not reflect services in France because there were no physicians - the elite of the profession - in the colony, and the bulk of the medical care was handled by surgeons, of whom the most important was the surgeon-major - the surgeon responsible for the 
care of the military. There apparently were a considerable number of surgeons at Louisbourg, probably due to the regulation requiring a surgeon on any vessel with a crew of more than 21 . Other medical personnel included apprentices, the Brothers of Charity (a religious order which operated the hospitals) and mid-wives.

It was only in 1735, when the post of 'Lieutenant of the first Surgeon to the King' was established at Louisbourg, that there was any official control over the surgeons in Ile Royale. Meanwhile in the other colonies (Port-Toulouse, Ile St-Jean, Port-Dauphin), these functions devolved on the surgeon-major. His first duty was to provide care for the military. Even if he was not part of the military organization, he always accompanied the troops. Other duties including shaving the soldiers and officers (or having his apprentice do it), giving expert testimony on medical subjects at tribunals, performing autopsies, approving sick leave or return to France ('Certificats d'invalidité'), and recommending hospitalization.

Once the patient entered the hospital, the surgeon-major could no longer care for him because the Brothers of Charity, who ran the hospital, had their own surgeon and guarded their prerogative so jealously that it was not until 1739 that they were persuaded even to let the surgeon-major visit their hospital! (The main purpose of these visits was probably to determine when soldiers were well enough to be released.) The surgeon-major could also care for civilians so long as it did not interfere with his obligations to the troops. Most surgeon-majors engaged in other activities, typically of a commercial nature, in order to augment their incomes.

\section{DISEASES AND REMEDIES AT ILE ROYALE}

Examination of contemporary correspondence and surgeons' bills gives some insight into the kinds of problems that were met and the treatments employed. Accidents of course were common: fractures, loss of sight, hernias, gunshot wounds, contusions and abrasions. Gout was treated with bandages soaked in alcohol. Rheumatic complaints often required that the victim return to France to take the waters. Fistulas, scabies, sunstroke, scurvy, pneumonia, smallpox and typhus were all described. Venereal disease required a return to France since the Brothers of Charity refused to deal with it. Epilepsy was likewise an excuse since it was felt that the climate at Fort Louisbourg was bad for this and many other complaints. Insanity was treated either by returning the victim to France or restraining him (depending, one suspects, on his position in the establish- 
ment). The remedies were the traditional bleeding, purging and blistering as well as the imbibing of infusions or teas and potions. The instruments available to the surgeons included basins for bleeding and shaving, bullet forceps, dental forceps, lancets, spatulas, probes, scissors, and needles as well as scales, weights, and mortar and pestles for preparing the various medications.

\section{CONCLUDING REFLECTIONS}

Three questions come to mind in contemplating the art of medicine in Pre-Loyalist New Brunswick. How healthy were the Indians and the Acadians? Did their treatments work? Are we better off today? There is no reason to think the life expectancy of New Brunswick's inhabitants was any less than that of Europeans of the same period. It is probable that the Indians were indeed quite healthy in the pre-contact period, due more to the survival of the fit than to their system of medicine. The Indian way of life was based on a total acceptance of nature in which they saw themselves as occupying a small part. With this degree of acceptance their system worked well enough in the sense of permitting a relatively stable and healthy population. However the system was totally inadequate to cope with European infections, alcohol and technology. They were highly susceptible to the first two and in the course of a few generations were seduced by and became totally dependent on the last.

In trying to decide if any of their treatments 'worked', we encounter difficulty in defining what it means for any treatment to 'work'. No controlled studies exist and in evaluating an uncontrolled treatment one must allow for the ubiquitous and potent placebo effect as well as the vis medicatrix naturae. Both healer and patient have a strong need to believe in whatever treatment is prescribed, and thus to concur that a good result is obtained because of the treatment, a poor result in spite of it. Obviously the primitive life of most of the Acadians and all of the Indians promoted the survival of the fittest. In looking at individual treatments some appear to have merit, others to be quite useless if not actually dangerous. Dr. Frank Chandler of Dalhousie University has been studying Micmac herbal medicine for some fifteen years and has identified a number of botanical products which look promising. Among these are pink Lady's Slipper which was used as a sedative and hypnotic and appears indeed to have some active pharmaceutical principle, and the Sweet Fern and Bunchberry which were used for poultices in skin diseases and appear to have some objective value in the treatment of psoriasis and eczema.

Are we better off? 
We are very good at curing some of the diseases which afflicted the Indians and Acadians, but unhappily these have been replaced by a new series of diseases which we are not very good at curing. We have the power to alleviate most symptoms, but often times the power is poorly used. As to our ability to comfort, it is a role not generally accepted by most of the health care professionals. The Indians and to a lesser degree the Acadians were peoples living in harmony with nature and accepting their limited role with limited expectations.

Much of the effort and expense of the present health care system is devoted to maintaining the unfit and the elderly at an ever increasing cost. When the Indians of New Brunswick broke their winter camp and moved on in search of food any who were too old or weak to keep up with the march were left behind to die. Today, it is now tacitly agreed, and doubtless will soon be openly stated, that such treatments as coronary by-pass, CAT scans and radiation therapy are not available to patients beyond a certain age. While ethics committees wrestle with the question of when to terminate life-support systems and allow 'death with dignity', the people turn in their thousands to the promises of Oral Roberts and outright quackery such as laetrile.

The Micmac buoins would have understood. Plus ça change, plus c'est la même chose.

\section{JOHN MACKAY}

Saint John Regional Hospital

\section{Notes}

1 A.H. Clark, Acadia: the Geography of Early Nova Scotia to 1760 (Madison: University of Wisconsin Press, 1968); pp. 71-74 provide a summary of what the term 'Acadian' meant to different protagonists at different periods.

2 Philip K. Bock, in Handbook of North American Indians, v.15: Northeast, ed. Bruce G. Trigger (Washington: Smithsonian Institution, 1978), p. 117.

3 Virginia P. Miller, 'Aboriginal Micmac population: a review of the evidence,' Ethnohistory, 23/2 (1976), pp. 117-127. This author presents several arguments supporting the claims of much higher aboriginal populations to be found in the earliest historical accounts. She points out that regular contact with European fishing boats was established at least a century before the first permanent settlement (Port Royal 1605). During this period, dependence on inferior trade foods, together with the effect of alcohol, could have caused a rapid reduction in native population without requiring either epidemics or hostility from the European 
visitors. A pre-contact aboriginal population of 35,000 , i.e. on the order of ten times the mid-eighteenth century Micmac population, is proposed.

4 Bock, pp. 110-111. The Micmac moved from place to place in pursuit of the available food supply, but this movement was not random. Rather it followed the same pattern year after year, with each 'moon' designated according to the dominant food source. Moreover there was a super-imposed two phase annual cycle, whereby families tended to disperse during the winter months and concentrate during the summer at well-established camp sites.

5 ibid., p. 119.

6 Leslie Francis Stokes Upton, Micmacs and Colonists: Indian-white relations in the Maritimes, 1713-1867 (Vancouver: University of British Columbia Press, 1979), pp. 5-6. Natalie B. Stoddard, The Micmac Indians of Nova Scotia (Halifax: Nova Scotia Museum, 1960).

7 Olive Patricia Dickason, Louisbourg and the Indians: a study in imperial race relations, 1713-1760 (Ottawa: Department of Indian and Northern Affairs, 1976), p. 46. All such estimates are imprecise, and in any case it does not follow that at any given time a particular area contained the maximum number of inhabitants which it could in theory support.

8 Alfred G. Bailey, The Conflict of European and Eastern Algonkian Cultures, 1504-1700, 2nd ed. (Toronto: University of Toronto Press, 1969). Chapter 5 provides a detailed discussion of the effects of European Trade goods on Indian culture and the relationship between the races.

9 Upton, p.4.

10 Virgil J. Vogel, American Indian Medicine (Norman: University of Oklahoma Press, 1970), pp. 152, 159.

11 Marc Lescarbot, Nova Francia: a Description of Acadia, 1606, trans. P. Erondelle (London: Routledge, 1928), p. 148. Several of the early French authors refer to this custom, e.g. Diéreville, Relation of the Voyage to Port Royal in Acadia or New France, ed. J.C. Webster (Toronto: Champlain Society, 1933), p. 146. The reason for it is obscure, save that fat has a very high caloric and satiety value, and was therefore much craved by a people often living in hunger. From a medical viewpoint, the practice would give concern because of the risks of inducing a lipid pneumonia. If this practice was in fact widespread, it could well have had an effect on survival rates among the newborn.

12 Diéreville, p. 155 . This figure of 15-20 lbs. keeps turning up in different places, suggesting that many students were impressed by what appears to be a guess ('must have') rather than an accurate measurement. Nevertheless the message is clear from all accounts that life moved from famine to gluttony in a manner conducive to digestive problems, especially in older people.

13 Lescarbot, pp. 218-219.

14 This very brief survey of Micmac skills in treating disease is extracted from the following sources: Upton, chapter 1, especially regarding supernatural medicine, pp. 10-15. The Micmacs had less difficulty than contemporary medicine does in developing a unified concept of physical and spiritual healing. Bailey, chapter 7 . 
W.D. Wallis, The Micmac Indians of Eastern Canada (Minneapolis: University of Minnesota Press, 1955), chapter 7, pp. 120-136 gives an outline of Micmac concepts of physiology and a list of remedies; chapter 8 discusses mental processes and interpretation of dreams. Laurie Lacey, Micmac Indian Medicine: a traditional way of health (Antigonish, Nova Scotia: Formac, 1977). W.B. Stewart, Medicine in New Brunswick (Moncton: Moncton Publishing Company, 1974). Nicolas Denys, The Description and Natural History of the Coasts of North America (Acadia), ed. W.F. Ganong (Toronto: Champlain Society, 1908), pp. 415-418. Fr. Chrestien Le Clerq, New Relations of Gaspesia, ed. W.F. Ganong (Toronto: Champlain Society, 1910), chapter 13, pp. 215 et sqq. and chapter 20, pp. 296 et sqq. Arthur F. Van Wart, 'The Indians of the Maritime Provinces, Their Diseases and Native Cures,' Canadian Medical Association Journal, 59, 573-577.

15 Clark, pp. 77, 90-91. The Company of New France had been formed in 1627 for the purpose of promoting the North American fur trade; in 1632, when by the Treaty of St. Germain-en-Laye Acadia passed into French hands, it was able to establish 'the first Acadian agricultural settlement which did not have a broken subsequent history' (p. 90); 'There became established by 1654 a resident population, more or less sendentary and agricultural from which a large proportion of the later Acadians were descended' (p. 101); pp. 397-400 Origins of the French settlers in Acadia. It is commonly stated that the original Acadian settlers came chiefly from La Rochelle, Saintonge and Poitou, but this is based largely on the distribution of similar family names, and different conclusions can be reached depending on whether one compares names of particular groups of original settlers or those of later populations. It seems likely that the present Acadian population has a much wider French origin than just these three districts.

16 Naomi Griffiths, The Acadians: Creation of a People (Toronto: McGraw-Hill Ryerson, 1973), pp. 33, 60. Other estimates vary.

17 ibid., p. 33: Not only was infant mortality extremely low; Acadians lived long, and septuagenarians were common.' I do not doubt the septuagenarians, but one wonders about the completeness of statistics on infant mortality, which always have a disproportionate effect on average longevity. It is a fact however, that Acadian populations tended to increase rapidly, which implies a certain degree of vigor, if not necessarily health.

18 Stewart, pp. 1-7, 28-30.

19 Es-tu bâdré de tes vivres - médecine traditionnelle en Acadie, Collection Folklore Acadien, I (Moncton: Universite de Moncton, 1979). This work is fairly comprehensive but many of the treatments described are part of an oral tradition which suffers from a certain lack of precision as to detail. What is worse, many of the methods are undoubtedly modified from the 18th century version.

20 The influence of the priests was of course much less in pre-deportation Acadia than in the nineteenth century, if only because they were few in numbers, so that many settlements saw a priest only for brief visits.

21 Linda M. Hood, Surgeons and Surgery in Ile Royale (Ottawa: Department of Indian and Northern Affairs, 1976). 